\title{
1946 Seçimleri ve Uluslararası Politikadaki Yansımaları: Soğuk Savaşın Eşiğinde Çok Partili Siyasal Hayata Geçiş ${ }^{*}$
}

\section{Yusuf Tekin ** İşat Sanalioğlu**}

Öz

Türkiye'de çok partili siyasal hayatın başlangıcı olarak kabul edilen 1946 seçimleri Türk demokrasi tarihindeki en önemli seçimlerden biridir. Cumhuriyetin ilanının ardından, ilk defa birden fazla siyasi partinin katıldığ 1946 seçimleri, gerek Türk Siyasal hayatına getirdiği yenilik, gerek seçim sürecine yönelik tartışmalar ve gerekse sürecin dış politikayla ilişkisi bağlamında akademik camiada büyük ilgi görmektedir. 1946 seçimlerini iç politika bağlamında değerlendiren çok sayıda çalışma mevcuttur. Ancak seçimlerin dış dünyadaki yansımalarına ilişkin yeterli sayıda çalışmadan bahsetmek mümkün değildir. Bu çalışmada başta ABD ve İngiltere olmak üzere Batı demokrasileri ve Sovyet Rusya’nın Türkiye'deki seçim sürecine bakışı irdelenmeye çalışılacaktır. Bu bağlamda çalışmada seçimlerin içerisinde cereyan ettiği iç ve dış politika koşullarına değinildikten ve sürece dair tartışmalara kısaca yer verildikten sonra, seçimlerin dönemin uluslararası politikası dâhilinde taşıdığı anlam ve bahsi geçen ülkelerin seçimleri yorumlayışı mercek altına alınacaktır.

\section{Anahtar Kelimeler}

Çok Partili Siyasal Hayat, 1946 Seçimleri, Demokratikleşme, Türk Dış Politikası, Soğuk Savaş.

\footnotetext{
* Geliş Tarihi: 17 Haziran 2020 - Kabul Tarihi: 17 Kasım 2020

Bu makaleyi şu şekilde kaynak gösterebilirsiniz:

Tekin, Yusuf ve İrşat Sarıalioğlu (2021). "1946 Seçimleri ve Uluslararası Politikadaki Yansımaları: Soğuk Savaşın Eşiğinde Çok Partili Siyasal Hayata Geçiş”. bilig - Türk Dünyası Sosyal Bilimler Dergisi 96: 1-32.

** Prof. Dr., Ankara Hacı Bayram Veli Üniversitesi - Ankara/Türkiye ORCID ID: 0000-0002-1385-2945

yusuf.tekin@hbv.edu.tr

${ }^{* * *}$ Dr. Öğretim Üyesi, Ankara Hacı Bayram Veli Üniversitesi, İ.İ.B.F., Uluslararası İlişkiler Bölümü Ankara/Türkiye ORCID ID: 0000-0001-7835-0746 irsat.sarialioglu@hbv.edu.tr
} 


\section{Giriş}

20. yüzyılı domine eden her iki dünya savaşı da siyasal sistemler üzerinde ciddi değişimler yaratmıştır. Hobbsbawm' ın imparatorlukların can çekiştiği yüzyıl olarak tanımladığı 19. yüzyıl bittiğinde dünya üzerindeki imparatorlukların tamamına yakınının yıkıldı̆̆ı, form değiştirdiği ve yerlerini ulus devletlerin aldığı görülmektedir.

Bu değişim sürecini ilk etapta, Birinci Dünya Savaşı tetiklemiş ve eski imparatorluk toprakları üzerinde ulus devletlerin kurulmaya başladığı bir süreç yaşanmıştır. Ulus devletlerin birçoğu ise, kurumsallaşma aşamalarını otoriterlik çizgisine çok yakın bir aşamayla geçirmişlerdir. İkinci Dünya Savaşı ise bu geleneğin kırılmasını sağlamış ve dünyanın birçok bölgesinde, Batı demokrasilerinin yaygınlaştığı yeni dünya düzeninin ortaya çıkmasını tetiklemiştir.

Türkiye de bu anlamda uluslararası gelişmelerle paralel bir biçimde, İkinci Dünya Savaşının hemen sonrasında çok partili siyasal hayata geçerek, demokratik blokla birlikte hareket etme kararı vermiştir. Bu konjonktürde gerçekleşen ve ilk defa birden fazla siyasi partinin katıldığı 1946 seçimleri çokça tartışılmıştır. İç politikada demokratik bir seçim olup olmadığı, iktidarın muhalefet üzerindeki baskıları, seçimlerin gerçekleşme usulleri vb konular uzun süre gündemde kalmışken, uluslararası alanda seçimlere ilişkin yapılan yorumlar ise devletlerin dış politikaları çerçevesinde değişiklik göstermektedir. 1946 seçimlerini iç politika bağlamında değerlendiren çok sayıda çalışma mevcuttur. Ancak seçimlerin uluslararası alandaki yansımalarına ilişkin yeterli sayıda çalışmadan bahsetmek mümkün değildir. Bu çalışmanın temel amacı da Türk siyasal hayatında bir dönüm noktası niteliği taşıyan 1946 seçimlerinin dış dünyadaki yansımalarını ortaya koymak ve bunları dönemin uluslararası politikası çerçevesinde değerlendirmektir. $\mathrm{Bu}$ amaç için, başta İngiltere, ABD, Fransa ve İsviçre olmak üzere dönemin önde gelen Batı demokrasileri ve Sovyet Rusya seçilmiştir.

Bu bağlamda ilk etapta, İkinci Dünya Savaşını izleyen yıllarda uluslararası alanda yaşanan siyasal gelişmelerle dönemsel Türk dış politikası arasında bağ kurularak Türkiye'de çok partili siyasal hayata geçiş sürecine etkisi ortaya konulmaya çalışılacaktır. Ardından ise, bunu anlamlandırmaya yardımcı olması açısından iç politikada yaşanan değişim sürecine, seçimlerin içerisinde 
cereyan ettiği siyasal ortam ve koşullara kısaca değinildikten sonra makalenin temel problemine odaklanılacaktır.

Çalışmada temel probleme odaklanırken ülke temelli bir metodolojik ayrımdan ziyade tematik bir ayrım tercih edilmiştir. Bu yöntem dâhilinde, ilk etapta seçilen ülkelerin Türkiye'de çok partili hayata geçiş düzenlemesini nasıl karşıladıkları ve bahsi geçen değişimin sebeplerine dair yorumları üzerinde durulacaktır. Ardından ise, seçim sürecinde Türkiye'deki siyasal havanın, basının durumunun, seçime katılan partilerin, süreçte öne çıkan liderlerin dış dünyadaki algılanış biçimiyle ülkelerin seçim tahminlerine yer verilecek ve akabinde seçim sonuçlarıyla seçimlere ilişkin tartışmaların uluslararası arenada nasıl ele alındığı sorununa odaklanılacaktır. Son olarak ise, 1946 yılında Soğuk Savaşın temel iki karşı ülkesi olarak öne çıkan ve makalede kullanılan arşiv kaynaklarının da sürece en etkin müdahil olan yabancı aktörler olarak ortaya koyduğu İngiltere ve Sovyet Rusya'nın tutumlarının altı çizilerek çalışma içerisinde elde edilen bulgular dönemin uluslararası politikası bağlamında değerlendirilecektir.

Çalışmanın, temel kaynağını Dışişleri Bakanlığı arşiv belgeleri (Türk Diplomatik Arşivi-TDA) oluşturmaktadır. Bu temel kaynak, yayınlanmış İngiltere Dışişleri Bakanlığı belgeleriyle desteklenmiş ve ardından da Rus arşivlerine dayanılarak oluşturulan literatürden yararlanılarak kullanılan arşiv kaynakları zenginleştirilmeye çalışılmıştır. Arşiv kaynaklarının yanı sıra konuya ve dönemin dış politikasına ilişkin temel literatürden de faydalanılmıştır.

\section{Türkiye'de Çok Partili Hayat ve Geçiş Saikleri}

Türkiye'de çok partili siyasal yaşama geçiş için daha önce Terakkiperver Cumhuriyet Fırkası (TCF) ve Serbest Cumhuriyet Fırkası (SCF) örnekleri yaşanmış, ancak gerek konjonktürel yaklaşımlar ve gerekse muhalif bir siyasi yapıya tahammül konusunda yeterince demokratik bir tutum sergilenememiş olması nedeniyle başarısız olunmuştur.

TCF bir anlamda kendiliğinden ortaya çıkmış bir partidir ve Kurtuluş Savaşı süreci içinde ortaya çıkan fikir ayrılıklarının parlamento ve siyasete yansıması olarak değerlendirilebilir. SCF ise, güdümlü bir muhalefet deneyimi olarak kurgulanmış, bu nedenle de uzun ömürlü olamamıştır.

İsmet İnönü’nün Cumhurbaşkanı ve Cumhuriyet Halk Partisi (CHP) Genel Başkanı olmasını müteakip yaşanan gelişmeler dikkatle incelendiğin- 
de 1945 yılına değin, yeniden çok partili hayata geçiş ile ilgili bir gündem karşımıza çıkmamaktadır. Bu anlamda ilk bakılabilecek kaynak 29 Mayıs 1939 tarihinde toplanan CHP Beşinci Büyük Kurultayıdır. Kurultay'da çok partili hayat ile ilgili hiçbir mesaj dikkat çekmemektedir. Hatta tam tersine Müstakil Grup tartışmaları yapılırken Genel Sekreter Fikri Tüzer "tek fırkalı kalmanın faziletleri” üzerine konuşmuş, bunun ülke için en uygun siyaset olduğunu belirtmiştir (Koçak 2017: 74). İzleyen siyasi ortam ve tartışmalarda da çok partili hayata geçişle ilgili hiçbir işaret söz konusu değildir. Örneğin, 1943 Kurultayında parti programında tek parti sisteminin gereklilikleri dile getirilmiştir (Koçak 2017: 327).

Çok partili hayata geçiş arzusu, İkinci Dünya Savaşı sonrası gündeme gelmiştir. Savaşın sona ermesini müteakip yaşanan gelişmeler sonrası Cumhurbaşkanı İnönü çok partili demokratik siyasal hayata geçişe ilişkin mesajlar vermeye başlamışıır. Bu mesajları İkinci Dünya Savaşını izleyen olaylarla birlikte değerlendirmek gerekir. Savaş sonunda tüm dünyada, otoriter yönetim tarzlarına karşı şiddetli bir reaksiyon ve öfke oluşmuştu. Savaşın sonuyla beraber devletlerin idare tarzı dünyanın barış ve güvenliğiyle sıkı sıkıya ilişkili görülmekte ve birlikte değerlendirilmekteydi. Otoriter eğilimler gösteren rejimler, yenilgiyle birlikte itibardan düşmüş ve tüm dünyada demokrasi rüzgârları esmeye başlamıştı. Kişi onuru ve özgürlüğü bakımından olduğu gibi toplumların güvenlik ve selameti bakımından da demokrasinin otoriter rejimlere üstün olduğu kanaati demokrasilerin zaferiyle birlikte, özellikle Batı dünyası için, önemli bir uluslararası ilişkiler prensibine dönüşmüştü (Burçak 1977: 43).

Türkiye için ise İkinci Dünya Savaşı'nın sonunda ortaya çıkan uluslararası durum, savaş dönemine göre çok daha zordu. Zira savaşın ardından, Türkiye savaş boyunca kaçındığı, savaşın beraberinde getirdiği uluslararası konjonktürle iştahı açlan Kuzey komşusuyla baş başa kalmak tehdidiyle, yüzleşmek durumunda kalmıştı (Aydın 2002: 475). 1943 yılında Stalingrad zaferinden sonra, Sovyetler cephede elde ettikleri zaferleri uluslararası politikada birer kazanıma dönüştürme yolunu tercih etmiş ve bu çerçevede Türkiye’ye yönelik dış politikasını değiştirmişti. Nitekim 19 Mart 1945 tarihinde bir nota ile 20 yılı aşkın bir süredir yürürlükte olan Türk-Sovyet Dostluk ve Tarafsızlık Antlaşması'nı yenilemeyeceğini, bildirmiş ardından da Haziran 1945 'te Boğazlardan üs ve Doğu Anadolu'dan toprak talep etmişti (Bilge: 
300-315). Moskova’nın bu ağır baskısının yanı sıra, bu dönemde uluslararası politikada karşı karşıya kalınan yalnızlık da Türkiye’yi epey zor bir duruma itmekteydi. Zira, Türkiye'nin, Sovyet Rusya karşısında denge arayışı içerisinde girdiği İngiltere'yle, savaşa girmemesinden dolayı ilişkileri bozulmuştu. ABD ise bu kadar uzağında olan bölgelere müdahale etme kararını henüz almamıştı (Ulman 1961: 61).

Türkiye San Francisco konferansına katılmak için, İngiltere'nin talebi üzerine Almanya ve Japonya'ya karşı, böyle bir konjonktürün içerisinde savaş ilan etmekteydi. 23 Şubat tarihinde TBMM'nde savaş ilanı kararı alınmış, karar esnasındaki tartışmalarda müttefiklerin arzularını yerine getirme çabas1 dile getirilmişti (Koçak 2017: 272). Bu tartışmalarda özellikle Başbakan Saracoğlu ve Şemsettin Günaltay'ın konuşmalarındaki demokrasi vurguları da dikkat çekicidir (TBMM-ZC, 7-15: 127-130).

Sovyet baskısı karşısındaki yalnızlığını Batı'yla ittifakla aşmaya karar veren Türkiye için San Francisco konferansı önemli bir dönüm noktası olmuştur. Cumhurbaşkanı İnönü, Konferansa katılacak olan Türk heyetine Türkiye'de pek yakında çok partili hayatın başlayacağını ilan etme yetkisi vermiştir (Burçak 1977: 46). İnönünnün verdiği talimatı Türk heyetinde Dışişleri Bakanı Hasan Sakanın yanında üçüncü delege olarak yer alan Feridun Cemal Erkin şöyle özetlemektedir:

Amerikalılar çok partili demokrasiyi ne zaman kuracağımızı sizlere sorabilirler. Böyle bir soruya şöyle cevap veriniz: Türkiye Cumhuriyeti tarihinde Atatürk büyük bir reformcu olmuştur. İnönü'nün rolü reformları raylarında perçinleştirmek ve Atatürk'ün de arzu ettiği gerçek demokrasiyi kurmak olacaktır... Harbin ortaya çıkardığı çeşitli tehlike ve sorunlar buna imkân vermedi. Savaş bitince bu amacı gerçekleştirmek Cumhurbaşkanının en aziz arzusudur. (Burçak 1977: 45-46, Ekici 1997: 275)

Türkiye San Fransisco'da, Birleşmiş Milletler Anayasa'nı kabul etmekle bu anayasanın demokratik ilkelerine uygun, daha hür bir rejime geçmeyi taahhüt etmiş oluyordu. Diğer taraftan San Francisco'daki Türk heyeti de eş zamanlı olarak Reuters Ajansı muhabirlerine savaştan sonra Türkiye'de her tür demokratik akımın gelişmesine izin verileceği yolunda beyanatta bulunmaktaydı (Karpat 2015: 229). Konferans devam ederken Cumhurbaşkanı 
İnönü de, 19 Mayıs Gençlik ve Spor Bayramı Törenlerinde Gençliğe Sesleniş’inde şu sözlerle ilk defa çok partili hayata geçiş imasında bulunmaktaydı:

Türk Gençleri!

Memleketimizin siyasi idaresi; Cumhuriyetle kurulan halk idaresinin her istikamette ilerlemeleri ve şartlariyle, gelişmeğe devam edecektir. Harp zamanlarının ihtiyatlı tedbirlere lüzum gösteren darlıkları kalktıkça, memleketin siyaset ve fikir hayatında demokrasi prensipleri daha geniş ölçüde hüküm sürecektir. En büyük demokrasi müessesemiz olan Büyük Millet Meclisi, ilk günden itibaren idareyi ele almış ve memleketi demokrasi yolunda mütemadiyen ilerletmiştir. Büyük Meclisin şimdiye kadar parlak bir surette ispat ettiği hakikat; halk idaresinin memleketi serbest düşüncelere ve hürriyet hayatına alıştırıp eriştirmesi ve geçmişte olan otoriter idarelerden daha kuvvetli olarak vatanda anarşiyi ve sözü ayağa düşürmeyi kaldırması olmuştur. Büyük Meclis, az zaman içinde büyük inkılâplar geçirmiş bir memleketin, sarsıntılara uğramadan, daha ziyade ilerlemesini temin edecektir. Harp yıllarında biz de, birçok memleketler gibi, fena hastalıklar geçirdik. Yabancı propagandaları ve yabancı fikirler bizde de yuvalar bulmak istidadını gösterdi. Harp zamanlarının haksız kazanç hırsları memlekete çok ıstırap çektirdi. Yabancı siyasetlerin inip çıkısları, bazı kimselerde kötü taklit hevesleri uyandırdı. Bütün bu fenalıklara karşı, Türk milleti kendi varlığını dikkat ve metanetle korumuştur. Harp kazançlarının kirleri ise, hiçbir suretle, idare ve iktidar başında bulunanlara bulaşmamışıtır (Sürekli alkışlar). (Ayın Tarihi 138: 51-53)

Cumhurbaşkanının bu konudaki ikinci açıklaması 1 Kasım 1945 tarihli yeni yasama yılının açılış konuşmasıdır. Bir önceki yasama yılı açılış konuşmasında, Türkiye Cumhuriyeti'nin, “iç idaresinde sağlam demokratik ve milli bir siyaseti takip" ettiğini belirtip, hükümete ve sisteme yönelik eleştirileri taklitçi bir zihniyet olarak değerlendirip (TBMM-ZC, VII-2-14: 2-8) ve hatta "Harp sonunda ve sonrasinda uyanmak istidadı gösterecek yeni taklit arzularına da, kesin olarak karşı koyacağız." diyerek bu konuda bir değişiklik düşünmediğini ima eden (TBMM-ZC, VII-2-14: 8) Cumhurbaşkanı'nın bir yıl sonraki konuşmasındaki uzun demokrasi vurgusu dikkat çekmektedir. 1 Kasım 1945 tarihli konuşmasında Cumhurbaşkanı, 
"Demokratik karakter bütün cumhuriyet devrinde prensip olarak muhafaza olunmuştur. Diktatörlük, prensip olarak, hiçbir zaman kabul olunmadıktan başka, zararlı ve Türk milletine yakışmaz olarak daima itham, edilmiştir”, demekte ve ardından da tek eksiğin bir muhalefet partisinin olmayışı oldugunu belirtmektedir:

...Bizim tek eksiğimiz, Hükûmet Partisinin karşısında bir parti bulunmamasıdır. Bu yolda, memlekette geçmiş tecrübeler vardır. Hattâ iktidarda bulunanlar tarafından teşvik olunarak teşebbüse girişilmiştir. İki defa memlekette çıkan tepkiler karşısında teşebbüsün muvaffak olmaması bir talihsizliktir. Fakat memleketin ihtiyaçları şevkiyle, hürriyet ve demokrasi havasının tabiî işlemesi sayesinde, başka siyasi partinin de kurulması mümkün olacaktır... O zamana kadar bir karşı partinin kendiliğinden kurulabilip kurulamayacağını ve kurulursa, bunun Meclis içinde mi, Meclis dışında mı, ilk şeklini göstereceğini bilemeyiz. Şunu biliriz ki, bir siyasi kurul içinde prensipte ve yürütmede arkadaşlarına taraftar olmayanların hizip şeklinde çalışmalarından fazla bunların, kanaatleri ve programları ile açıktan durum almaları siyasi hayatımızın gelişmesi için daha doğru yol; milletin menfaati ve siyasi olgunluğu için daha yapıcı bir tutumdur... (TBMM-ZC, VII-3-20:7-9)

Bu konuşma, yukarıda özetlenen uluslararası konjonktür çerçevesinde değerlendirilebilir. Buna ek olarak, bu konuşmadan kısa bir süre önce, 6 Eylül 1945 tarihinde, ABD'li 6 kişilik bir parlamenter heyetin, ardından da 11 Ekim'de farklı bir heyetin Türkiye'ye geldiği ve bir takım görüşmeler yapıldığı bilinmektedir (Yetkin 1983: 247). 1946 yılında ise ABD ve İngiltere'yle kurulan ilişkinin ivme kazandığını ve Türkiye'nin Sovyet Rusya karşısındaki yalnızlığının yavaş yavaş dağıldığını görmekteyiz. Bu bağlamda, İngiltere Dışişleri Bakanı Bevin, 21 Şubat 1946'da Avam Kamarası'nda yaptığı konuşmada Sovyet Rusya tehdidine atfen, “Türkiye'nin uydu bir devlete dönüştüğünü görmek istemediği” ni belirtmiştir (Sever 1997: 35). Ardından, Nisan 1946'da, Sovyet Rusya'nın taleplerine ABD’nin, vefat eden Washington Büyükelçisi Münir Ertegün'ün cenazesinin Amerikan donanmasının en büyük zırhlılarından biri olan Missouri'yle İstanbul Boğazına göndererek bir nevi cevap vermesi (Ulman 1961: 73-74) de İkinci Dünya Savaşı'nın ardından Türkiye’nin Batı demokrasileriyle ilişkilerinin geldiği noktayı görmek açısından önemlidir. 


\section{Cumhuriyet Tarihinin En Tartışmalı Seçimi}

Bu gelişmeler sonrasında önce Nuri Demirağ ın önderliğinde Milli Kalkınma Partisi (MKP) ve ardından da CHP içinde muhalif kimlikleriyle tanınan Dörtlü Takrir sahiplerinin öncülüğünde Demokrat Parti (DP) kurulmuş, böylelikle Türkiye'de çok partili siyasal hayat yeniden başlamıştır.

DP'nin kurulması, iktidar partisinde ciddi bir tedirginliğe yol açmıstır. Henüz teşkilat olarak çok partili rekabete hazır olmayan CHP yönetimi, önce yerel seçimlerin erkene alınması kararını vermiş, DP yönetimi ise henüz teşkilatlanma sürecini tamamlayamadıkları için, bu kararı protesto ederek seçimlere katılmamıştır. Bu esnada toplanan CHP Kurultayında muhalefetin bu tavrı ciddi rahatsızlık konusu olmuştur. Kurultayda genel seçimlerin de erkene alınması tartışmaları yapılırken, DP'nin bu konuda ne tür tepkiler gösterebileceği üzerinde özellikle durulmuştur. Genel Başkan İnönü’nün kurultay konuşmasının genelinde, DP’nin genel seçimlere katılmasına yönelik beklentiler egemendir, hatta bu hususta üstü kapalı bir tehditten dahi bahsetmek mümkündür:

Şüphe etmem istemem ki, şimdiye kadar kurulmuş olan partiler, seçime, parti olarak gireceklerdir. Şimdilik hiçbir partiye mensup olmayan siyaset adamlarımızın da, seçime katılarak memlekete hizmet imkânını arayacaklarını umarım. Milletin iradesinin açık bir surette belli olması için, bu kadar dikkat gösterdiğimiz halde, partilerin veya bağımsız olanların bir bahane bularak seçime girmekten kaçınacaklarını farzetmek istemem... Bundan başka, iktidara karşı siyasi parti teşkil edip, samimi olarak bizim idaremizi beğenmiyen vatandaşları topladıktan sonra, onları oy sandığı başından menetmek, vatandaşları, meşru mücadele yolundan ayırmak demektir. (B.C.A. 218-860-1:3)

Seçim kararı alındıktan sonra DP yönetimi sadece 34 il ve 160 ilçede teşkilatlanabildiği için seçime girmek konusunda tereddüt yaşamıştır (Eroğul 1990: 15). Ancak 16 Haziran'da Ankara’da bir nevi gayri resmi bir kongre toplanmış ve seçime girilmesi kararı alınmıştır. Toplantı sonrasında yayınlanan Beyanname'de de sürece ilişkin eleştiri ve endişelerin altı çizilerek "sadece ülkenin yüksek çıkarları” için seçimlere katılım kararı alındığı belirtilmiştir (İnan 2006: 211). 
1946 seçimleri Türkiye'de çok partili hayata geçiş sonrası yapılan ilk seçim olmanın yanı sıra başkaca vasıflarıyla da çokça tartışma konusu olmuştur. Cumhuriyet döneminin bir anlamda ilk "baskın seçimi” olması, seçim sürecinde yaşanan siyasi baskı tartışmaları, "açık oy ve gizli sayım” tanımlamaları, basın üzerinde uygulanan sınırlama eleştirileri gibi gerekçeler bu tartışmaların ana unsurlarıdır (Koçak 2012, 524-532, Timur 1994: 54-55).

Genel seçimlerin bir yıl erkene alınmasına ilişkin CHP Kırklareli Milletvekili Nafi Atuf Kansu tarafından verilen teklif TBMM'de 10 Haziran 1946 tarihli oturumda görüşülmüştür. Sert tartışmalar eşliğinde yapılan görüşmelerde DP adına söz alan milletvekilleri "iktidarın el çabukluğuyla yeniden intihaba gitmek" yolunu seçerek bir anlamda hile yaptığının altını çizmişlerdir. Onlara göre, iktidar partisini buna iten şey "diğer partiler genişlerse Halk Partisi zaafa düşer endişesi”dir. İktidar partisi ise, ısrarla bunun demokratik ülkelerdeki olağan uygulamalardan birisi olduğunu İngiltere örneği üzerinden öne sürmüş ve seçimlerin yenilenmesinin Türk siyasetine "taze hayat" getireceğini dile getirmiştir. İktidar partisi sözcülerine göre, DP gibi yeni partilerin, kurulur kurulmaz "mevkii iktidara gelmeleri” doğru değildir, bunun için "zaman geçmek lazımdır", dolayısıyla acele etmemelerini ve olanlara rıza göstermelerini talep etmişlerdir. Nihayetinde önerge 379 oyla kabul edilmiş ve seçimler yaklaşık bir yıl erkene alınmıştır (TBMM-TDVII-8-24:81-87). Yeterince örgütlenememiş olması nedeniyle seçimlere DP 273 adayla 46 ilde girebilmiş, CHP ise, tahmin edileceği üzere bütün illerde 464 aday ile seçime katılmıştır.

Seçime ilişkin propaganda süreci de çok tartışmalı geçmiştir. DP, propaganda sürecinde, İçişleri Bakanlı̆̆ının illere gönderdiği bir genelgeyle iktidarın uyguladığı baskıdan ciddi şekilde etkilenmiştir. 11 Temmuz 1946 tarihinde bir Beyanname yayınlayarak bu baskıların anayasaya aykırı olduğuna dikkat çekmiştir. Bahsi geçen genelgede İç İşleri Bakanlığı köylerde yapılmakta olan zehirleyici propagandaları önlemek üzere partilerden gönderilen kimselerden hangi parti adına hareket ettiklerini gösterir vesika istemektedir. DP; köylere gönderilen siyasetçilerinin bu gerekçeyle "geldikleri yerlere iade edilmelerini” eleştirmiştir (BCA, 30-1-0-0:1). İçişleri Bakanlığı ise, DP’ye verdiği cevapta, "mevzubahis tamimin yanlış anlaşıldığını" aslında bu genelgenin "seçim propagandası vesilesiyle hasıl olan bu karışı ve nazik durum karşısında her yere sokulan, her sözü söyleyen ve kim oldukları belli olma- 
yan kimselerin hüviyetlerini anlamak" amacı güttügünü belirtmiştir. Aynı konuda CHP de bir açıklama yapmış ve DP'nin Beyannamesini "halkı kendilerine acındırarak daha fazla rey toplamak arzusundan doğan bir propaganda beyannamesi” olarak tanımlamıştır (Cumhuriyet, 12 Temmuz 1946).

Muhalefet başta “açık oy ve gizli tasnif” olmak üzere seçim güvenliğinin olmadığı, Cumhurbaşkanı İnönü’nün parti genel başkanı kimliğini de taşıması hasebiyle yaptığı gezilerin propagandaya dönüşüp, tarafsızlığını ortadan kaldırdığı, başta radyo olmak üzere tüm iletişim araçlarının devlet tarafından sadece CHP'nin kullanımına sunulduğu ve özellikle sıkıyönetim komutanlığınca alınan tedbirlerin muhalefeti hareketsiz bıraktığı gibi konularda eleştiriler öne sürmüştür. CHP ise, "yıkıcılar ve intikamcılar hareketi" olarak tanımladığı DP'ye yönelik, "anarşi özlemi içinde olma”, irticacı ve Rus taraftarı olma iddialarında bulunmuştur (Eroğul 1990: 15).

"Baskın seçim", "hileli seçim", "açık oy gizli tasnifle yapılan seçim” gibi vasıflarla anılan 1946 seçimleri (Barutçu 1977: 323, Ahmad 2010: 125-126, Demirel 2014: 480) sonucunda CHP'nin 395 ve DP'nin ise 66 milletvekili ile TBMM'de temsil edileceği açıklanmıştır. DP yönetimi, sonucun böyle olmadığını, seçimlere hile karıştırıldığını, oyların CHP lehine değiştirildiğini, DP'ye oy vermeme konusunda vatandaşların baskı altına alındığını iddia etmiştir (Tekin vd 2019: 132). DP 37 ilde seçim sonuçlarına itiraz etmiş, 27 Ağustos tarihinde bir İnceleme Komisyonu kurulmuş, fakat hiçbir değişiklik olmamıstır (Albayrak 2004: 91).

\section{Seçimlerinin Ülke Dışındaki Yansımaları}

\section{Çok partili hayata geçiş sürecine ilişkin değerlendirmeler}

Çok partili hayata geçiş süreci ve 1946 seçimleri hem Türk siyasal hayatında yarattığı değişiklik hem de uluslararası konjonktürün hassas konumundan dolayı ülke dışında da büyük ilgi görmüştür. Bu konuda atılan adımlar, başta İngiltere ve ABD olmak üzere Batı devletleri tarafından Türk siyasal sisteminin demokratikleşmesi yolunda oldukça mühim gelişmeler olarak yorumlanmıştır (TDA/534/8729404, TDA/534/5406265, TDA/502/3764708, TDA/525/5843888, TDA/540/12698692). Bu çerçevede, İngiltere'nin Ankara Büyükelçisi Maurice Peterson'ın Dışişleri Bakanı Ernest Bevin'e gönderdiği raporda yer alan "gelecek ne gösterirse göstersin Türkiye demokratikleşme yolunda tehlikeli bir kritik noktayı atlatmıştır” (BDOFA IV-B-1: 
18-19) değerlendirmesinin muadillerine tüm Batı kamuoyunda rastlamak mümkündür.

Türk siyasal hayatındaki bu mühim değişiklikler Sovyet Rusya tarafından da ilgiyle takip edilmiştir. Jamil Hassanli, Sovyet arşivlerine dayanarak yaptığ çalışmasında Sovyet Rusya’nın Türkiye'deki süreci, “istenmeyen” bir hükümetin "dost" hükümete dönüşmesi beklentisiyle yakından takip ettiğini belirtmektedir. Hassanli'ye göre; Sovyet Rusya'nın Potsdam Konferansı'ndan sonraki sessizliği, bu süreçte Boğazlara ve Doğu vilayetlerine ilişkin talepleri içeren yeni bir notanın gelmeyişi de Türkiye'de oluşan değişim üzerine bir süre yürütmeye karar verdiği "bekle-gör" politikasından ileri gelmektedir (Hassanli 2011: 221).

Uluslararası camianın Türkiye'de çok partili hayata geçişin sebepleri üzerine yaptığı değerlendirmeler ise ülke içi literatürümüzde de karşılaştığımız üzere dış politika kaygıları üzerinde toplanmaktadır. Batı ülkeleri atılan adımları esas olarak, Türkiye'nin İkinci Dünya Savaşı'nın sonundan itibaren uluslararası politika alanında yaşadığı yalnızlık ve Sovyet tehditleri karşısında denge arayışı siyasetiyle açılamaktadır. Genel kanaat muhtemel bir Sovyet taarruzuna karşı koyabilmek için hükümetin Anglosakson demokrasilerinin kendisini desteklemesine her zamankinden daha çok ihtiyacı olduğu ve bu yardımı ancak tamamen demokrat bir hükümet şeklini hayata geçirmekle sağlayabileceğinin farkında olduğu yönündedir (TDA / 525 / 5843888, TDA / 525 / 5845640, TDA / 540/ 12698604, TDA / 525 / 5844542, TDA / 502 / 3764813, BDOFA IV-B-1: 18-19).

Bunun yanı sıra Fransız basınındaki bazı makalelerde, Türkiye'nin yanaşmak istediği Batı demokrasileri tarafından diktatörlükle itham edilmesinin, kendisini zor bir durumda bıraktığı ve hükümetin bu eleştirileri bertaraf etmek istediği de belirtilmektedir (TDA/525/5843888). Bir bütün olarak bahsi geçen değerlendirmelerde tek parti rejimine karşı oluşan toplumsal hoşnutsuzluk ikinci planla atılırken, bunların arasında sadece İngiltere'nin daha doğrusu dönemin İngiliz Büyükelçisi David Kelly’nin, değişimi İsmet İnönü’nün şahsi fikirleriyle de ilişkilendirdiğini görmekteyiz (BDOFA IVB-3: 426-430).

Moskova Basın Ataşeliğinden gelen evraklarda ise değişimin genellikle CHP yönetiminin toplumda uyandırdığı öfke ve muhalefetle açıklandığı, dış poli- 
tika meselelerine çok fazla değinilmediği görülmektedir (TDA/964/18857, TDA/964/18864).

Seçim sürecinin dış dünyadaki yansımalarına bakıldı̆̆ında, ilk göze çarpan unsur, Cumhuriyet Halk Partisi, Demokrat Parti, Milli Kalkınma Partisi, Liberal Demokrat Parti, Türkiye İşçi ve Çiftçi Partisi ve Yalnız Vatan İçin Partisi olmak üzere seçimlere altı partinin katılmasına (Tuncer 2003: 62) rağmen uluslararası kamuoyunun ilgisinin $\mathrm{CHP}$ ve DP üzerinde toplanmasıdır. Bunun yanı sıra köken olarak aynı kadrolardan oluşmasına atıfla iki partinin siyaset ve yönetim prensiplerinin temelde aynı olduğu, partiler arasında yalnızca ekonomi-politik konusunda ayrışmanın bulunduğu yorumlarıyla da sıklıkla karşılaşılmaktadır. Ayrıca, bu hususta yapılan yorumların Türkiye'nin İkinci Dünya Savaşı'nın sonundan itibaren şekillenen dış politikasını da kapsadığını, iki parti arasında bu açıdan bir ayrım bulunmadığının da altının çizildiğini görmekteyiz (TDA/502/3764763, TDA/525/5843888, TDA/540/12698692, TDA/534/5406265, BDOFA IV-B-3: 426-430).

İngiltere ise, iki parti arası farklıklar konusunda, diğer ülkelerden farklı olarak, birkaç hususu daha bahis konusu yapmaktadır. DP’nin yeni kurulduğu dönemde, İngiltere'nin Ankara Büyükelçisi olarak görev yapan Peterson, Dışişleri Bakanı Bevin'e gönderdiği raporda, Kemalizm'e ve Kemalizm’in altı ilkesine sadık olan partinin CHP'den tek önemli farkını özel teşebbüsün arttırılması ve devletçiliğin zayıflatılması vurgusu olarak tanımlamakta ve Türkiye'nin içerisinden çıktığı parti kadar vatansever ve Kemalist ikinci bir partiye sahip olduğu yorumunu yapmaktaydı (BDOFA IV-B-1: 18-19). Fakat Peterson'ın ardından Ankara'ya atanan yeni Büyükelçi D. Kelly'nin yorumlarının farklı olduğunu görmekteyiz. D. Kelly, Bevin'e gönderdiği raporlarda, DP'nin muhafazakâr, aşırı sağcı ve gerici eğilimleri olabileceğinden şüphelenmekte olduğunu ve bu noktalarda CHP'den farklılaşmaya başladığını belirtmektedir (BDOFA IV-B-1:107). Yeni Büyükelçi bu hususta Başbakan Saracoğlu' yla dahi görüşme yapmış ve Başbakana DP içerisinde Atatürk'e yapılan erken muhalefetle karşılaştırılabilecek ölçüde bir dinsel hareketin canlanma ihtimali olup olmadığını sormuştur. Buna karşın, Saracoğlu ise DP'nin CHP'ye göre, daha sağ kanatta yer aldığının kesinlikle doğru olduğunu belirtmiş; fakat bununla birlikte parti içerisinde gerici olarak nitelendirilebilecek bir eğilimin pek göze çarpmadığını, bahsi geçen 
eğilimin daha küçük muhalefet grubu olan MKP'de mevcut olduğunu söylemiştir (BDOFA IV-B-1: 111-112).

Sovyet Rusya ise, liderliğini Celal Bayar'ın üstlendiği muhalefet partisini endişeyle karşılamıştır. Sovyet Rusya’nın Ankara Büyükelçiliğinin hazırladığı raporlarda "büyük burjuvanın projesi", "Batı'nın adamı" (Hassanli 2011: 250) olarak anılan Bayar'ın siyasete atılması, Türkiye'nin Batı'ya entegrasyonunu kuvvetlendirme politikasının bir parçası olarak değerlendirilmiştir (Hassanli 2011: 223). Bunların dışında, CHP ve DP arasındaki farklara ilişkin Sovyet Rusya’nın bakış açısı da Batı kamuoyuyla büyük ölçüde uyuşmaktadır. Moskova Basın Ataşeliğinden ve Moskova Büyükelçiliğinden gelen raporlarda, Sovyet Rusya kamuoyunda DP'nin liberal eğilimine atıf yapılmakla beraber iki partinin temelde benzer prensiplere sahip olduğunun konuşulmakta olduğu belirtilmektedir (TDA/964/18849, TDA/4023/1772864). Bununla beraber, Rus kamuoyu, DP'nin dış politika alanında CHP'ye yaklaştığının ve Sovyet Rusya'yla dostluk siyasetinin karşısında yer alan Saracoğlu’nun dış politika prensiplerini tasvip ettiğinin de farkındadır (TDA/4023/17728641).

Seçim sürecinde Türkiye'deki basının durumu ve basına getirilen kısıtlamalarla gazete kapatma uygulamaları da uluslararası alanda dikkat çekmiştir. Örneğin, dönemin ABD Basın Ataşesi Demon, Basın Yayın Umum Müdürü Nedim Veysel ile yaptığı görüşmede, bir taraftan demokrasiyi ve basın serbestini ilan ederken diğer taraftan gazete kapatmaya teşebbüs edilmesi üzerine, $\mathrm{ABD}$ basının Türkiye'deki seçim sürecinin demokratik niteliğine dair lisanlarını değiştirdiklerini belirtmektedir. Bahsi geçen görüşmede, Demon, Amerikalı gazetecilerin seçim hürriyetine bu kadar ehemmiyet vermelerinin Rusyàyı çevreleyen memleketlerde tam bir demokrasinin tesisi gayesinden ve Rusya endişesinden kaynaklandığını (TDA/2303/4862684) belirtmesi ise konumuz açısından ayrıca anlamlıdır.

Fransız ve Rus kamuoyunda da, Türk hükümetinin radyoyu, haber alma servislerini ve birçok gazeteyi CHP'nin emrine tahsis ettiğine ve muhalif basına baskı ve zor kullanıldığına yönelik eleştirilere sıkça rastlanmaktadır (TDA/525/5845640, TDA/525/5844609, TDA/964/18874). Bunun yan1 sıra Rus basını, CHP İstanbul İl Başkanı Alaattin Tiridoğlu’nun gazete yazarlarını yanına çağırarak kendilerinden seçimlerde CHP'yi destekleyeceklerine dair yazılı taahhütname aldığını iddia etmektedir (TDA/964/18874). 
Bu hususta sadece İngiliz parlamenter Philips Price'ın Manchester Guardian'da yayınlanan makalesinde faklı bir yaklaşıma rastlamaktayız. İngiliz parlamenter, "Demokrasiye Doğru Giden Modern Türkiye Cumhuriyeti" başlıklı makalesinde, basın özgürlüğü meselesi de dâhil olmak üzere Türkiye'deki seçim sürecine ilişkin tartışmalı bütün hususları, dikkat çekici ölçüde olumlu değerlendirmiştir. Price’a göre; Türkiye'de, muhalefet gazetelerinin birçoğu dâhili meseleler üzerinde kuvvetli tenkitlerde bulunmaktadır. Bu dönemde Yugoslavya ve Bulgaristan gibi Balkan ülkelerinde, hiçbir matbuat muhalefetinin mevcut olmadığının altını çizen Price'a göre, Türkiye'de belirli sınırlar dâhilinde tenkit hareketlerinin teşvik edilmesi, Türkiye'nin bölgede Batı demokrasilerine en yakın ülke olduğunu kanıtlamaktadır (TDA/534/5406265).

Türkiye'deki seçim sürecine ilişkin uluslararası kamuoyunun ilgisini çeken bir diğer husus ise İsmet İnönü nün seçim sürecinde oynadığı roldür. İnönü özellikle Batı kamuoyu tarafından, aldığı kararla övgüye mazhar olmuş ve Batı basınında yer alan haberlerde, Türkiye'yi böylesi kritik bir dönemde harici tazyike karşı birleştiren önder olarak yer almıştır (TDA/502/3764708). Fakat bunun yanı sıra, Büyükelçilik raporlarında İnönü’nün, seçim mücadelesindeki bazı tutumları eleştirilere konu olmuştur. Bu bağlamda, İngiltere'nin Ankara Büyükelçisi Kelly'nin, 3 Temmuz 1946'da Dışişleri Bakanı Bevin’e gönderdiği raporundaki değerlendirme özellikle önemlidir. Raporda tüm ulusu temsil etmesi gereken Cumhurbaşkanının otoritesini bir parti yönünde kullandığının ve böylelikle diğer partileri zor bir durumda bıraktığının altı çizilmiş ve DP'nin bu duruma ilişkin eleştirileriyle "şimdiye dek Türk milletine liderlik edebilecek yegâne politik figür olan Cumhurbaşkanının pozisyonunun anormalliğinin de ilk defa tartışılmaya açıldığı" (BDOFA-IV-B-1: 117-120) belirtilmiştir.

Seçim sürecine dair uluslararası kamuoyunun ilgisini çeken bir diğer konu da halk nezdinde büyük prestij sahibi, Mareşal Fevzi Çakmak'ın DP listesinden bağımsız aday olarak seçimlere katılmasıdır. Bu dönemde, Çakmak uluslararası kamuoyu tarafından, İnönü'nün rakibi, halefi ve DP'nin en önemli kozu olarak değerlendirilmiştir (BDO-IV-B-1: 117-120, TDA/540/12698632, TDA/503/178493).

Seçimlere dair ülke dışındaki değerlendirmelerin bir diğer ilgi çekici tarafı da seçim tahminleriyle partilerin bu süreçteki avantaj ve dezavantajlarına 
dair yorumlardır. ABD, İngiltere, Fransa ve İsviçre'de, Atatürk tarafından kurulmuş olması, ülkeyi zor durumlardan kurtarmış olması ve çok iyi teşkilatlanmış olması sebebiyle CHP'nin seçimden lider çıkacağı, bununla beraber yeni partiler arasında bu partiyle boy ölçüşebilecek ve hükümetin siyasetini kontrol edebilecek tek partinin de DP olduğu yorumlarına sık sık rastlanmaktadır. Ayrıca, hükümeti demokrasinin serbestçe gelişimine mâni olmakla itham eden ve iktisadi hürriyet taraftarı olan DP'nin özellikle ekonomi politik prensibinden dolayı şehirlerde etkinlik göstereceği hemen her ülkenin kamuoyu tarafindan paylaşılan bir değerlendirmedir (TDA/502/3764763, TDA/540/12698604, TDA/525/5845640).

Bu değerlendirmelere ek olarak dönemin İngiliz Büyükelçisi seçim öncesi Türkiye'deki duruma dair hazırladığı raporunda, seçimlere yaygın bir dış tehdit korkusu altında gidildiğini, hükümetin bunu seçim politikasında iyi bir koz olarak kullandığını dile getirmekte ve bu durumun seçimde CHP'nin lehine işleyeceğini belirtmektedir. Ayrıca Büyükelçi, mevcut durumda kimsenin bir muhalefet zaferi beklemediğini de sözlerine eklerken, kendisinin DP kadrolarının Türkiye'nin iç ve dış politika açısından içerisinde bulunduğu kritik süreçte mevcut hükümetin yerini doldurabilecek yetkinlikte olmadığını düşündüğünün altını çizmektedir (BDOFA-IV-B-1: 117-120). Büyükelçiye göre, mevcut koşullar, 'dere geçerken at değiştirilmez’ prensibine iyi bir örnek oluşturmaktadır ve Türkiye'de, parlamento etkin bir muhalefetle güçlendirilirken bunun ilerisine gidilip DP liderlerinin mevcut hükümetin yerini alması Türkiye'nin müttefiklerinin endişeyle izleyeceği bir olasılıktır (BDOFA-IV-B-1: 117-120, Babaoğlu 2017:396).

İngiltere Büyükelçisinin dış tehdit korkusunun CHP tarafından seçim propagandasında kullanıldığı değerlendirmesinin, Sovyet Rusya tarafından da paylaşıldığını görmekteyiz. Sovyet Büyükelçisine göre, CHP’nin, seçim kampanyası neredeyse tamamen Sovyet Rusya karşıtı propaganda üzerine bina edilmiştir ve halk "Bolşevik tehdidiyle korkutulmuştur" (Hassanli 2011: 225).

Batı kamuoyunun seçim tahminlerinde de birleştĭgini görmekteyiz. Genel tahmin, DP'nin ekonomi siyasetinden ötürü tüccarlardan (BDOFA IV-B1: 111-112) ve nüfuz sahibi iş çevrelerinden (BDOFA IV-B-3: 426-430), oy olarak şehirlerde, sahil şeridinde ve özellikle de Türkiye'nin güney batısında (BDOFA IV-B-1:107) çoğunluğu elde etmesi, ülkenin en ücra yerlerine 
kadar teşkilatlanmış durumda olan CHP'nin, Cumhurbaşkanı İnönü'nün Kurtuluş Savaşı kahramanı ve Atatürk'ün varisi olma özelliklerinin de etkisiyle kırsal alanda güçlü olacağı yönündedir. Ayrıca Batı kamuoyu yeni kurulmuş bir parti olan DP'nin mecliste çoğunluğu ele geçirmesini beklememekte; 50-100 arasında değişen milletvekili sayısıyla ciddiye alınması gereken bir muhalefet partisi işlevi yürüteceğini ön görmekte ve bu durumu önemli bir başarı olarak değerlendirilmektedir (TDA / 502 / 3764763 , TDA / 540 / 12698604, TDA / 525 / 5844542, TDA / 540 / 12698692, TDA / 540 / 12698632).

Batı kamuoyunda yaygın olan sayısal seçim tahminlerine Sovyet Rusya'ya ilişkin incelenen belgelerde rastlanmamıştır. Bununla beraber, Ankara'daki Sovyet Büyükelçiliği'nin Mayıs 1946'da Moskova’ya gönderdiği raporda, DP'nin yükselişinin devam ettiği ve partinin CHP'yle rekabet edebilir duruma geldiği belirtilmektedir (Hassanli 2011: 224).

\section{Seçim ve seçim tartışmalarına ilişkin değerlendirmeler}

Yukarıda da belirtildiği üzere, 1946 seçimleri, Cumhuriyet döneminde ilk defa olarak birden fazla partinin yer alması ve tek dereceli olması nedeniyle, Batılı hükümetler ve kamuoyu tarafından demokrasi yolunda atılmış kritik bir adım olarak değerlendirilmiştir. ABD, İngiltere, Fransa ve İsviçre’nin, seçimlere ilişkin yorumları genelde, Türkiye'nin ilk defa hakiki bir seçim tecrübesi yaşadığı, bunun demokrasiye ivme kazandıracağı ve Türk siyasal sisteminin Batı demokrasileri modeline yaklaşacağı yönündedir. Yorumlarda, seçimleri kimin kazandığından ziyade 1923 sonrası Türk siyasal sisteminde ilk defa tek parti devletinin dışına çıkılmış olmasının önemi üzerinde durulmakta, bu durumun seçimi kimin kazandığından önce geldiğinin altı çizilmektedir (TDA/502/3764813, TDA/540/12698651, TDA/525/5845640, TDA/540/12698692, TDA/502/3764708, TDA/540/12698737, BDOIV-B-1: 117-120, BDOFA IV-B-1: 18-19).

Batı kamuoyunun değerlendirmelerinde dikkat çeken bir diğer ortak nokta da, 1946 öncesi dönemin genellikle, otoriter bir dönem olarak yorumlanması, akabinde ise kontrollü bir dille bahsi geçen sürecin anlamlandırılmaya çalışılmasıdır. Örneğin, ABD'de yayınlanan Star Gazetesi, tek parti dönemini "yarı-diktatörlük" olarak adlandırmakta, ardından ise, Atatürk’ün işin başından itibaren, zamanla muhalefet partilerinin doğacağını gördüğünün altını çizmektedir (TDA/502/3764763). 
Türkiye'nin şimdiye kadarki siyasal yapısında "inkâr edilemez surette otoriter ve totaliter temayüller" bulunduğunun altını çizen İsviçre basını da bu duruma, Batılılaşmayı kararlaştıran Türkiye'yi karşı ihtilalden koruyacak bir yol olarak başvurulduğunu belirtmekte ve Atatürk'ün bir liberal partinin teşkiline müsaade ederek sistemi yumuşatmaya teşebbüs ettiğinin altını çizerek SCF tecrübesine atıf yapmaktadır (TDA/540/12698737, TDA/540/12698604).

Fransız basınında ise tek parti sistemi ve otoriterlik değerlendirmeleri, Rusya karşılaştırması üzerinden sunulmaktadır. Epoque gazetesi, Atatürk ile Çar. I. Petro arasında benzerlik kuran bir yaklaşımla, Atatürk'ün I. Petro'nun yaptığı yeniliklerin benzerlerini Türkiyede uygulamaya soktuğunu, çabalarının parti mücadelelerine kurban gitmemesi için de tek parti sistemini elzem gördüğünü belirtmektedir (TDA/525/5844542). Mode gazetesinin, seçimlere dair yorumu ise daha güncel bir Rus yönetimi benzerliğine atıf yapmaktadır. Gazete önceki seçimlerin totaliter plebisitleri andırdığını ve Türkiye'nin komşusu Sovyetlerinkine oldukça benzediğini belirtmekte ve Batı Avrupa sistemine yaklaşan seçimleri bu sebeple, Türkiye tarihinde önemli bir dönüm noktası olarak değerlendirmektedir (TDA/525/5843888).

İngiliz parlamenter Price’ın, makalesinde ise, tek parti sisteminin eleştirisinin döneminin uluslararası siyasetinin bir yansıması olarak ve İngiltere'nin dış politika önceliklerini işaret eden bir biçimde Türkiye ve Balkan devletleri karşılaştırması üzerinden yapıldığını görmekteyiz. Mareşal Tito, Dimitrof ve İsmet İnönü nün en ön safta gelen şahsiyetler olduğu, Yugoslavya, Bulgaristan ve Türkiye'de icra kuvvetlerine olağanüstü yetkiler verilmesini eleştiren Price, Türkiye'nin bu iki devletten Temmuz 1946 itibariyle açıkça farklılaştığının altını çizmektedir. Yazar, Türkiye’nin şimdiye kadar yürüttüğü "mütefekkirler ve askerler sınıfının kontrolünde otoriter idare sisteminden" ayrılarak Batı demokrasilerindeki gibi parlamenter bir hükümete doğru gitmekte olduğunu belirtmekte ve dönemin Başbakanı Recep Peker'in kedisine şöyle dediğini belirtmektedir: "Sizin demokrasi şeklinizi elde etmeye çalışıyoruz. Bu yolda henüz tamamıyla muvaffak olmamış bulunuyorsak [da] gayemizin tam manasıyla bu hedefe varmak olduğuna şüphe etmeyin" (TDA/534/5406265). 
Bunun yanı sıra, seçimlere ilişkin, ABD ve İngiltere kamuoyunda çok fazla öne çıkmayan bir eleştiriye Fransa ve İsviçre basınında rastlamaktayız. Fransa'da Mode, İsviçre'de, "Gazette de Lausanne” ve Journal de Geneve, seçimlere komünistlerle sosyalistlerin girmesine müsaade edilmediğinin altını çizerek, sınırlı muhalefet prensibi sebebiyle Türkiye'de, Batı prensiplerine uygun tam bir demokrasiden bahsetmek için henüz erken olduğu yorumunu yapmaktadır (TDA/540/12698604, TDA/540/12698632, TDA/525/5843888).

Seçimlere ilişkin Sovyet kamuoyuna bakıldığında ise sürecin tamamen olumsuz bir zaviyeden ele alındığını görmekteyiz. Başta Moskova radyosu olmak üzere bir bütün olarak Sovyet basını seçimleri "göstermelik bir siyasi manevra” olarak değerlendirmektedir. Moskova basınında bu yorumun, genel olarak dört temel üzerine bina edildiğini görmekteyiz.

Bunlardan ilkini seçim sürecinde Türk basının durumu oluşturmaktadır. Örneğin İzvestiya gazetesi, Türkiye'de ve dünyada bazı çevrelerin, seçimler münasebetiyle Türk demokrasisini göklere çıkardığını hâlbuki gerçek durumun bambaşka olduğunu öne sürmekte ve Tan, Yeni Sabah ve La Turquie gibi muhalif gazetelere yönelik girişilen hareketleri bu düşüncesinin kanıtı olarak sunmaktadır. Zira gazeteye göre, bahsi geçen gazete binalarının yıkıldığı ve yazarlarının tevkif edildiği vakitten henüz birkaç ay geçmişken salt seçimlerin yapılabilmiş olması nedeniyle Türkiye'de demokrasi yolunda ilerleme olduğunu iddia etmek mümkün değildir (TDA/964/18874).

Diğer taraftan Rus basını, 31 Mayıs tarihinde gerçekleşen belediye seçimlerinin de Türkiye'de demokrasiye doğru bir ilerlemeden bahsedilemeyeceğini kanıtladığını öne sürmektedir. Belediye seçimleri esnasında birçok bölgede hükümet makamlarının tehdit ve hükümet nüfuzunu suiistimal etmek suretiyle seçmenlere baskı uyguladığını ileri süren Rus basını, bazı milletvekillerinin bu konunun araştırılmasına ilişkin taleplerinin reddedildiğinin de altını çizmektedir (TDA/964/18874).

Diğer taraftan yeni partilerin kurulması ve bu partilerin serbestçe hareket edebilmesi için yapılan değişikliğin yeterli olmadığını belirten Sovyet basınına göre, bu süreçte açlıp henüz üzerinden çok vakit geçmemişken kapatılan ve seçimlere katılamayan sol eğilimli partiler buna örnektir (TDA/571/9336605). 
Seçimlere yönelik Sovyet basınının öne sürdüğü en son ve belki de en önemli eleştiri, yeni kanunun gizli oy uygulamasına imkân tanımamasıdır. Bu durumu, Türk demokrasisinin iç yüzü olarak değerlendiren Sovyet basınında ilgili dönemde "gizli rey: işte Türk demokrasisinin iç yüzü", gibi yazı ve manşetlere sıkça rastlanmaktadır (TDA/964/18874).

Seçimlerin uluslararası alanda dikkat çeken bir diğer tarafı da sürece ilişkin tartışmalar ve meşruiyet konusudur. Washington Büyükelçiliğinden gelen raporda, seçimlerin $\mathrm{ABD}$ basınında ve kamuoyunda genel olarak olumlu bir değerlendirmeye tabi tutulduğunun altı çizilmektedir. Rapora göre ABD basınında seçimlere ilişkin muhalefetin eleştirilerine yer verilmekle beraber genel olarak yapılan yorumlar olumlu bir mahiyet taşımaktadır ve "İnönü’nün muhalefet partilerine seçimlerde CHP'yle rekabete girmek müsaadesi vererek Türkiye'yi harici tazyike karşı birleştirdiği” hususuna özellikle vurgu yapılmaktadır (TDA/502/3764708). Ayrıca Newsweek'in İstanbul muhabiri Knickerbocker'ın eğer bir sahtekârlık olduysa seçim mekanizmasının üst seviyelerinde olmuş olabileceği, özellikle İstanbul bölgesindeki kendi gözlemlerinin bu iddianın aksi yönünde olduğu değerlendirmesi de ABD basınında yer almıştır (TDA/502/3764813).

Fransız basını ise Celal Bayar ve Mareşal Çakmak'ın seçimlere olan itirazlarına yer vermiştir. Matın gazetesi, Bayar'ın serbest "seçim bahis mevzuu değildir. Biz seçimlere milli bir vazife olduğu için iştirak ediyoruz" yolundaki bir demecini yayınlarken (TDA/525/5844542), 26 Temmuz tarihli France Soir'da, hükümetin CHP'yi bütün vasıtalarıyla desteklediğini belirttikten sonra, Mareşal Çakmak'ın "milletin iradesine saygı gösterilmemiştir” demecine atıf yapmıştır (TDA/525/5845640).

25.7.1946 tarihli Manchester Guardian Gazetesi ise, DP'nin CHP'yi, hükümet otoritesini kullanarak oyları kendi lehine tezahür ettirmek için her hileye başvurmakla, itham ettiğini belirtmektedir. Ayrıca, 25.7.1946'da Londra Basın Ataşeliğinden gelen raporda, Londra basınının genel olarak "Ruslar tazyik kullanıldığını iddia ediyorlar" başlığını tercih ettiği belirtilmektedir (TDA/534/6025864).

İngiltere büyükelçiliğinin raporlarına baktığımızda ise, seçim sürecine ilişkin İngiliz basınına oranla, tartışmalar hakkında daha fazla bilgi ve yorum içeren bir üslupla karşılaşmaktayız. Dönemin Ankara Büyükelçisi Kelly, 
CHP ve DP'nin etkinliklerini değerlendirmek ve bir öngörüde bulunmak için hazırladığı raporuna, tek dereceli seçime geçiş düzenlemesinin, "birçoğu ortaçağa ait sosyal koşullarda yaşayan Türk insanına İngiliz ve Amerikan vatandaşlarının üstlendiği tüm seçim sorumluluğunu yüklemekte” olduğunu belirterek başlamaktadır. Hükümetin oy mekanizmasını ve seçimi hile ve aksaklık olmadan yürütülebilme ihtimalini, bir diğer ifadeyle teoride Batı demokrasilerine yaklaşan sistemin pratikteki işlerliğini sorgulayan Büyükelçi, bu şartlar altında, yerel kamu otoritesini kontrol eden hükümet taraftarlarının, genellikle partili olan vali, belediye başkanı ve köy muhtarlarının seçimleri düzenleyen teorik hükümlere pek fazla riayet edeceğini düşünmediğini belirtmektedir. Büyükelçiye göre, oy sandıklarının seçim merkezlerinde yerel otoritelerin kontrolü altında bir süre tutulacak olması da bu çerçevede değerlendirilmelidir. Diğer taraftan Büyükelçi, dönemin İçişleri Bakanlığı tarafından valilere, kaymakamlara, belediye başkanlarına ve hatta muhtarlara gizli bir genelge yollanarak, sadece Cumhurbaşkanı İnönü ve CHP'nin Sovyet taleplerine karşı koyabileceğinin, Sovyetler tarafından DP’ye arka çıkıldığının ve Türkiye'nin müttefiklerinin Celal Bayar ve partisine güvenmediğinin vurgulandığını, düşünmektedir (BDO-IV-B-1: 117120).

İngiliz Büyükelçiliğinin sene sonunda hazırladığı yıllık raporda ise, seçimlerde bazı antidemokratik olayların tespit edildiği, polis müdahalelerinin vuku bulduğu ve sonuçların değiştirildiğine dair kuşkuların olduğu belirtilmektedir. Bununla beraber raporda bahsi geçen uygulamalara başvurulmasının sonucu pek fazla etkilemediği belirtilmekte ve "yoktan yere muhalefete ve dışarıdaki düşman propagandaya meydan verildiği” yorumu yapılmaktadır (BDOFA IV-B-3: 426-430).

Moskova Basın Ataşeliğinden gelen raporlarda ise, başta Moskova Radyosu olmak üzere tüm Sovyet Rusya basınının Türk hükümetinin seçimlerin arifesinde seçmenlere tesir edebilmek için tedhiş ve tazyiki alabildiğinde arttırdığı, polis ve jandarma kuvvetlerinin vilayet ve köylerde yoğun baskı uyguladığı ve halkı seçim öncesi korku ve paniğe sürüklediği haberleriyle dolu olduğu belirtilmektedir. Ayrıca bahsi geçen haberlerde bunların neticesinde birçok DP üyesinin mağdur olduğu, tevkif edildiği ve hatta hükümete muhalif bazı kimselerin katledildiğine şahit olunduğu yazmaktadır (TDA/964/18874, TDA/964/18857, TDA/964/18843). 
Seçmenlere baskı ve zor kullanılmasının yanı sıra seçime dair usulsüzlük ve hile iddialarının, hem Ankara'daki Sovyet Rusya Büyükelçiliği'nin Moskovảya gönderdiği raporlarda (Hassanli 2011: 225) hem de Sovyet Rusya basınında sıkça yer aldığını görmekteyiz. Örneğin, bu bağlamda DP mümessillerinin İstanbul'un birçok bölgesinde seçim listelerini kontrol etmekten men edildikleri belirtilmekte ve hükümet makamlarının süreç içerisinde her türlü usulsüz yola başvurmaktan geri durmadıkları, hatta seçim sürecinde tüm hükümet mekanizmasının demokrasiye karşı çalıştığı yorumu yapılmaktadır (TDA/2752/13866667, TDA/964/18857, TDA/964/18845). Tüm Sovyet basınında yaygın olan bu kanaat neticesinde seçim sürecine dair yapılan haberlerde, "Türk basını ve seçimleri: yapılan sahtekarlık" ve "22 Temmuz'da doğması beklenen Türk demokrasisi doğmadan öldü” tarzında manşetlere sıkça rastlanmaktadır (TDA/964/18845).

\section{CHP ve DP'nin Soğuk Savaş'1}

Seçimlerin en çok tartışılan yönü olan meşruiyeti konusunun ülke dışında nasıl ele alındığına dair, incelenen evrak bağlamında ileri sürebileceğimiz ilk değerlendirme, süreç içerisinde vuku bulan hükümet baskılarının, seçmen iradesinin sandığa yansımadığı eleştirilerinin ve açıklanan sonuçlara dair tartışmaların çalışma içerisinde ele alınan bütün ülke kamuoylarında veya ülke merkezlerine gönderilen elçi raporlarında yer aldığı ve seçimlere dair bazı problemlerin olduğunun hemen herkesçe kabul edildiğidir. Bunun yanı sıra ülkelerin, Türkiye'yle kurduğu ilişkiye göre, basınlarında yer alan anlatım dili, seçilen örnekler ve yazının genel havası, bir diğer ifadeyle tarih yazımı önemli ölçüde değişmektedir.

Bu bağlamda, ilk göze çarpan husus Batı kamuoyunun bilhassa da İngiltere ve $A B D$ 'nin seçim problemleri konusunda münferit olaylara ve bu husustaki değerlendirmelere yer vermektense, genellikle muhalefetin beyanatlarına yer vermeyi, bir diğer ifadeyle beyanatı verene atıf yaparak DP liderlerinin görüşlerini alıntıladığı, Sovyet Rusya basınının ise sistematik olarak ve ayrıntılı bir biçimde seçim sürecinde yaşanan olaylara yer verdiği ve bunlar üzerinde geniş yorumlarda bulunduğudur. Bu noktada, seçimlerin, seçim tarihinin belirlenmesinden, adaylarla ilgili tartışmalara, propaganda sürecinde kamu gücünün kullanılmasından, açık oy gizli sayıma kadar birçok açıdan Türkiye'nin en tartışmalı seçimlerden biri olarak kabul edilmesine rağmen demokratik ilkelerle bağdaşmayan bu hususların İngiltere ve ABD 
basınında sadece muhalefetin iddiaları olarak yer almış olması dikkat çekici bir husustur.

Batı kamuoyu tarafından inşa edilen metinler çok partili hayata geçişin Türkiye'nin Batı'ya eklemlenmesi yolunda taşıdığı önemin altını çizerken, seçim problemlerini ikinci plana atan bir yazım üslubu tercih etmişlerdir. Hatta kullanılan bu dil sebebiyle, DP liderlerinin, özellikle de Köprülü ve Menderes'in, Britanya basınına çok öfkeli oldukları ve dönemin İngiltere Büyükelçisine "Majestelerinin hükümetinin CHP'yle özdeşleştiği” eleştirilerini yönelttikleri incelenen belgelerde görülmüştür (BDOFA-IV-B-1:176-177).

Türkiye'nin ilk çok partili seçimleri, ABD'nin Türkiye ve Yunanistan'ı desteklemeye karar verdiği Truman doktrinin ilanının yaklaşık sekiz ay öncesinde, Batı kampında İngiltere'nin ön planda olduğu ve Ortadoğu'daki siyasetini ve çıkarlarını henüz ABD’ye devretmediği bir dönemde gerçekleşmiştir. Bu durum, çalışma içerisinde incelenen belgelerde görülen İngiliz hassasiyetini açıklamaktadır. Aslına bakılırsa İngiltere hükümeti ve İngiliz Büyükelçiliğiyle DP arasında mevcut dönemde oluşan ve yukarıda bahsi geçen sorunların da temelinde bu yatmaktadır. Gerek Büyükelçinin raporlarında gerekse İngiliz basının kamuoyu oluşturma tarzında gözlemlenen CHP desteği de bundandır. Zira yukarıda da belirtildiği üzere, dönemin Büyükelçisi, DP'yi mevcut koşullarda Türkiye'yi yönetmeye ehil görmediğini, defalarca belirtmektedir. Hatta 3.7.1946 tarihli raporunda açıkça, Türkiye'de, parlamento etkin bir muhalefetle güçlendirilip sistem "demokrasi bloğu"na yakınlaştırılmışken, bunun ilerisine gidilip DP'nin mevcut hükümetin yerini almasını bir nevi kumar olarak değerlendirmekteydi. İngiltere'nin bu tavrı, "şark için iyidir", "doğu için bu kadarı kâfi”" (bon pour l'orient) anlayışının yanı sıra reel politiğe ve uluslararası güç dengelerine de dayanmaktadır. Belli ki İngiltere Soğuk Savaşın başlangıcında, Rusya’ya karşı ittifaka girişmekte olduğu mevcut yönetimin devamını kendisi için daha güvenli bir alan olarak da görmektedir. Zira çalışma içerisinde incelenen İngiliz raporlarında bu görüş açıkça ortaya konulmaktadır.

Seçim sürecinde İngiliz yorumunun tam karşısında ise, dönemin uluslararası güç dengesine uygun bir biçimde Sovyet Rusya yer almıştır. Yukarıda da belirtildiği üzere, Sovyet Rusya’nın seçim sürecinde tercih ettiği üslup, dikkat çekici boyutlarda olumsuzdur ve Türkiye'de çok partili hayata geçişin taşıdığı tarihsel öneme hiçbir vurgu yapılmaksızın tamamen seçim problemle- 
rine odaklanmıştır. Hatta Rus basının seçim sürecinde yürüttüğü bu şiddetli antipropaganda diğer ülkelerin dahi dikkatini çekmiştir. ABD, İngiltere ve Fransa’da Türk seçimlerine dair yer alan yazılarda Rusya’nın seçim sürecinde başta Moskova Radyosu olmak üzere Rus basını ve kamuoyu üzerinden yürüttüğü baskının psikolojik savaş boyutlarına ulaştığı yorumlarına sıkça rastlanmaktadır (TDA/534/5406265, TDA/525/5843888). Rusya'nın bu tutumu seçim sürecinde, Rusya'nın DP'ye arka çıtığı, hatta Rusya ve DP arasında zımni bir ittifak olduğu iddialarını beraberinde getirmiştir. Örneğin, Hüseyin Cahit Yalçın yönetimindeki Tanin Gazetesi’nin bu konudaki değerlendirmeleri dikkat çekicidir. Gazete, Rus radyosunun Türkçe yayınlarını referans göstererek, "Bolşevikler Maskeyi Yüzlerinden Attılar" "Demokrat Partisini Cevap Vermeye Davet Ediyoruz” gibi manşetleri sık sık kullanmışve devamında şu yorumlarda bulunmuştur:
Vatandaş! Moskofların radyolarında Türkçe olarak söylediklerini oku ve düşün! Memleketi onlardan kurtarmayı dış siyasetinin en birinci düsturu bilen Halk Partisi'nin etrafinda toplan! Vatani Vazifen bu- dur! "Memleketin içinde Türk vatanını Moskofların nüfuz ve hima- yesi altına koymak fikrine kapılmış bedbahtlar yahut Bolşeviklerin talimatı altında hareket eden sefiller varsa bunlar arttık belli olmalı- dır. (Tanin, 13 Temmuz 1946)

18 Temmuz tarihli nüshada ise; Hüseyin Cahit doğrudan Rus Hükümetinin Demokrat Parti'yi desteklediğini ifade etmiştir (Tanin, 18 Temmuz 1946).

Yukarıda gördügümüz üzere Türkiye'deki çok partili siyasal hayata geçiş Sovyet Rusya tarafından ilk başta "istenmeyen" bir hükümetin yerini "dost" bir hükümetin alabilme ihtimaliyle heyecanla karşılanmışır. Fakat elimizdeki veriler bunun ötesine geçip, Sovyet Rusya'nın DP'yle ittifaka giriştiğini söylemek için kâfi değildir. Kaldı ki, DP’nin bünyesinde barındırdığı isimler ve siyasal görüşlerinin, Sovyet Rusya tarafından endişeyle karşılandığı da bilinmektedir. Bu bağlamda, Sovyet Rusyànın tutumunu ilk etapta, 1945 yılından beri Türkiye ve Türk hükümeti üzerinde kurmaya çalıştığı baskı ve yıpratma siyasetinin bir uzantısı olarak değerlendirebiliriz. Bunun yanı sıra, nasıl ki İngiltere ve ABD'de seçimlere dair oluşan bakış açısının ardında, Soğuk Savaşın eşiğinde ittifak içerisinde girilen tarafı yıpratmama ve -belki de zımni olarak destekleme- stratejisi yatıyorsa Sovyet Rusya’nın bakış açısının ardında da tam aksine Batı'yla ittifak içerisine giren ve kendi taleple- 
rine böylelikle karşı durmaya çalışan tarafı yıpratma stratejisinin yattığı da düşünülebilir. Bu konuda Türkiye'nin Moskova Büyükelçisi Selim Sarper'in yorumu ise, Rusya'nın maksadının Türkiye'yi İngiltere ile ittifaktan ayırmak ve bu amaç için bir ilk adım olarak İnönü, Saracoğlu ve General Orbay’ı siyasal hayatın dışına itmek olduğu yönündedir. Ayrıca Serper'e göre Sovyet propagandası daha zayıf, daha az tecrübeli ve dolayısıyla sindirilmesi daha kolay bir hükümetin tesis edilmesine matuftur. Zira Sovyetlerin asıl hedefi, dünyanın birçok bölgesindeki hükümetlerle tesis ettiği bir biçimde yakın bir ittifak üzerinden nüfuz kurma politikasıdır (BDOFA-IV-B-1: 157-158).

Moskova'nın bu tutumunun neticelerine baktığımızda ise, sonucun hedeflenenin aksine bir yönde geliştiğini söylemek yanlış olmayacaktır. Şöyle ki, Moskova’nın yayınları ve seçimlere ilişkin tutumu ülke içerisinde ciddi bir öfkenin oluşmasını beraberinde getirmiş, muhalefet de dâhil olmak üzere tüm Türk basını bu durumu ülkenin iç işlerine bariz bir karışma olarak değerlendirmiş ve ülke içerisindeki Rusya karşıtlığı böylelikle daha da artmıştır (BDOFA-IV-B-1: 157-158). Bu çerçevede İngiliz Büyükelçisi'nin, ülke içerisindeki Rus karşıtlı̆̆ından dolayı, Sovyet Rusya’nın tutumunun DP'ye, aslında hiçbir fayda sağlamadığına aksine zararının dokunduğuna ve DP'nin muhaliflerine karşı propaganda imkânı sunduğuna dair yaptığg değerlendirme de anlamlıdır (BDOFA IV-B-3: 426-430).

\section{Sonuç}

Türkiye'de çok partili siyasal hayatın başlangıcı olarak kabul edilen 1946 seçimleri Türk demokrasi tarihindeki en önemli ve en tartışmalı seçimlerden biridir. Bir yandan çok partili demokrasi sürecini başlatırken, diğer yandan eşit ve adil ortamda gerçekleşmemiş olması, baskı ve zorlamaların varlığı, açık oy gizli sayım tanımlamasıyla özdeşleşmiş olması nedeniyle bu seçim, hem iç politikada ve hem de dış politikada birçok açıdan uzun süre gündemi meşgul etmiştir.

ABD’nin Moskova Büyükelçisi George Kennan'ın meşhur "uzun telgraf"ından altı ay, Churchill'in "demir perde indi" açıklamasını yapmasının üzerinden ise henüz beş ay geçmişken yapılan bu seçimler, uluslararası kamuoyunda, ilk sinyallerini veren Soğuk Savaş paradigması çerçevesinde değerlendirilmiştir. Bu sebeple Türkiye içerisinde cereyan eden tartışmalar ve 
seçimlerin meşruiyeti problemi uluslararası kamuoyunda ikincil bir öneme sahip olmuş, ülkeler seçim sürecini tamamen Türkiye'nin dış politikalarındaki yerine göre belirledikleri bir çerçeveden değerlendirmiştir.

Çalışma içerisinde incelenen arşiv kaynakları da, ülkelerin Türk siyasal hayatındaki bu mühim değişime yönelik tutumlarının sürecin başından itibaren kendi dış politika kaygıları etrafında şekillendiğini göstermektedir.

Sürecin en başında, muhalefet partilerinin kurulmasına olanak sağlayan düzenlemeler, Cumhuriyetin kuruluşundan itibaren uygulanan sistemi otoriter olarak tanımlayan Batı devletleri tarafından, Türk siyasal sisteminin demokratikleşmesi yolunda atılmış oldukça önemli ve kritik bir adım olarak değerlendirilmiştir. Bahsi geçen değişiklik Sovyet Rusya tarafından ise, ilk etapta, bir süredir dış politikada sorunlu bir ilişki yürüttügü Türk hükümetinin yerine "dost" bir hükümetin geçişini sağlayabilecek bir firsat olarak görülmüştür. Bu noktada, seçim sisteminde değişiklik meydana getiren düzenlemenin sınırlı bir muhalefete izin vermesinin, Sovyet Rusya kamuoyunda şiddetli eleştiri konusu yapılırken İngiltere ve ABD kamuoyunda pek ses getirmemesi de dikkat çekicidir. Diğer taraftan, Sovyet Rusya hariç tüm uluslararası camianın, Türkiye'de çok partili siyasal hayata geçişi İkinci Dünya Savaşı'nın sonundan itibaren uluslararası politika alanında yaşanan yalnızlık ve Sovyet tehditleri karşısında denge arayışı siyasetiyle ilişkilendirdiği görülmektedir.

Seçimlere katılan siyasal partilere ilişkin uluslararası alanda yapılan değerlendirmeler konusunda ilk göze çarpan unsur ise, seçim sürecine her ne kadar altı parti katılmış olsa da uluslararası camianın ilgisini CHP ve DP'ye yönlendirdiği ve MKP'nin ilk muhalefet partisi oluşunu çoğu zaman göz ardı ederek, bu rolü DP’ye biçtiğidir. DP; kurulduğu dönemde, Türkiye’de muhalefet partilerinin yer aldığı yeni siyasal hayatın teminatı olarak görülüp Batı tarafından sempatiyle karşılanmıştır. Sovyet Rusya ise, liderliğini "Batı'nın Adamı", "Büyük Burjuvanın Projesi” olarak adlandırdığı Celal Bayar’ın üstlendiği partiye ilk etapta endişeyle yaklaşmıştır.

Seçim sürecinde CHP ve DP arası farkların neler olduğu konusu da uluslararası alanda epey ilgi çekmiştir. Bu bağlamda, Sovyet Rusya da dâhil olmak 
üzere uluslararası kamuoyunda iki partinin, dış politika yönelimleri de dâhil olmak üzere, temelde benzer prensiplere sahip olduğunun sadece ekonomik yaklaşımlarının farklılaştığının altı çizilmiştir.

Seçimlere dair ülke dışındaki değerlendirmelerin bir diğer ilgi çekici tarafı da sonuçlara ilişkin tahminlerdir. ABD, İngiltere, Fransa ve İsviçre'de CHP'nin, özellikle kırsal alanda başarı göstererek seçimden lider çıkacağı, bununla beraber yeni partiler arasında bu partiyle boy ölçüşebilecek tek parti olarak gördükleri DP'nin, ekonomi-politik anlayışından dolayı şehirlerde, sahil şeridinde ve Türkiye'nin güney batısında etkinlik göstereceği düşüncesi hâkimdir. Bunun yanı sıra İngiltere ve Sovyet Rusya, seçimlere yaygın bir dış tehdit korkusu altında gidildiğini, hükümetin bu durumu seçim politikası çerçevesinde kullandığını dile getirmekte ve durumun seçimde CHP'nin lehine işleyeceğinin altının çizmektedir.

İncelenen belgelerde, seçimlere gidilirken Türkiye'deki basının durumunun ve basına getirilen kısıtlamalarla gazete kapatma uygulamalarının da uluslararası alanda eleştiri konusu olduğu görülmüştür.

Seçim sonuçlarına ilişkin ise, Batı kamuoyunda, yapılan yorumlarda, seçimleri kimin kazandığından ziyade 1923 sonrası Türk siyasal sisteminde ilk defa tek parti devletinin dışına çıkılmış olmasının önemi üzerinde durulduğunu, bu durumun seçimi kimin kazandığından ve seçim sürecinde ne yaşandığından önce geldiğinin vurgulandığını görmekteyiz. Örneğin, seçimlerin hemen ardından $\mathrm{ABD}$ basınında, seçimlerin “Türkiye'yi savaş sonrası otoriter kontrolün gönüllü olarak gevşediği tek ülke" yaptığı yorumları yer almıştır. Bu yorumlara göre, bölgesindeki diğer ülkeler "yüzlerini Rusya’ya ve Komünist diktatör yöntemlere çevirmişken” Türkiye yüzünü Batı'ya dönmüştür (TDA/502/3764813). İngiliz parlamenter Price'ın, çalışma içerisinde incelenen makalesindeki Balkan vurgusu ve Türkiye'yi sık sık Sovyet nüfuzunun yoğun olduğu Balkan ülkeleriyle karşılaştırması da tam olarak bu sebepten ileri gelmektedir.

$\mathrm{Bu}$ konuda tamamen olumsuz bir tavır takınan ülke ise, yine soğuk savaş paradigması çerçevesinde hareket eden, Sovyet Rusya olmuştur. Sovyet Rusya’ya göre, seçim sürecinde yaşanan meşruiyet problemleri, basına uygulanan baskı ve bilhassa da gizli oy prensibinin olmayışı 1946 seçim- 
lerinin Türkiye'de demokratikleşme yolunda atılan bir adım olarak görülmemesi gerektiğinin başlıca sebepleridir. Moskova, seçimleri tamamen bir siyasi manevra ve göstermelik bir girişimden ibaret görmektedir.

Diğer taraftan, çalışma içerisinde incelenen belgeler, seçim sürecinin demokratik ilkelere uygun olmadığı konusunun da bütün ülke kamuoylarında ve/veya ülke merkezlerine gönderilen elçi raporlarında yer aldığını ortaya koymaktadır. Bu noktada, Batı demokrasileri arasında Fransa ve İsviçre'de seçim problemlerine daha fazla yer verilirken, İngiltere ve ABD' nin seçimlere ilişkin problemli alanları dikkat çekici ölçüde hayırhah yorumladığını görmekteyiz. Sovyet Rusya ise İngiltere ve ABD'nin takındığı tavrın tam aksini sergileyerek sadece seçim problemlerini ve seçimlerin meşruiyeti meselesini ön plana çıkarmış, hatta Türk siyasal hayatının içerisinde bulunduğu bu mühim değişim sürecini seçimlerin meşruiyeti problemi ve hükümetle yaşadığı sorunlara indirgemiş, Türkiye'de çok partili hayata geçişin taşıdığı değere hiç önem atfetmemiştir.

Boğazlardan üs ve Doğu Anadolu'dan toprak taleplerine ilişkin Sarper'e Moskova'da iletilen sözlü notayla 1946 Ağustos'unda Türkiye’ye gönderilen tarihi notalar arası süreçte gerçekleşen 1946 seçimleri, Sovyet Rusya tarafından ilk etapta bir dış politika fırsatı olarak değerlendirilirken ülke içerisinde oluşan koşulların da etkisiyle zamanla Türkiye'ye uyguladığı baskı stratejisinin bir uzantısı halini almıştır. Seçimleri, hükümetin değişmesi için firsat olarak gören Moskova seçim süreci üzerinden, Türkiye'de muhalefet de dâhil olmak üzere herkes tarafından iç işlerine karışma olarak değerlendirilip tepki gösterilen bir kampanyaya girişmiştir. Bu durum, ülke içerisinde Sovyet Rusya- Demokrat Parti yakınlaşması iddialarını beraberinde getirmiş, hatta bu iddialar seçim sürecinde iktidar partisi tarafından kullanılmıştır. Buna karşılık yukarıda incelenen elçilik raporlarından da görüldüğü üzere DP'yi soğuk savaşın eşiğinde Türkiye gibi kritik bir ülkeyi yönetmeye ehil görmeyen İngiltere’nin seçim sürecinde izlediği siyaset ise DP tarafından eleştirilere konu olmuş ve böylelikle CHP-DP arasındaki seçim mücadelesi Soğuk Savaş'ın temel parametrelerinin içerisinde kendisine yer bulmuş ve neticede tıpkı Türkiye'deki çok partili yaşama geçiş kararında olduğu gibi seçim sürecinde de iç politikayla dış politikanın iç içe geçtiği bir konjonktür oluşmuştur. 
Bu çerçevede Türkiye'de çok partili siyasal hayata geçişin başlangıcı kabul edilen ve Türk demokrasi tarihi açısından özel bir öneme sahip olan 1946 seçimleri Soğuk Savaş sürecinde birçok ülkede karşılaşacağımız iç politika-dış politika etkileşimi ve ülkelerin iç siyasal gelişmelerinin uluslararasılaşmasının erken ve ilgi çekici örneklerinden birini oluşturmaktadır.

\section{Kaynaklar}

\section{Arşiv Kaynakları}

\section{Türk Diplomatik Arşivi (TDA)}

TDA/502/3764708.

TDA/502/3764813.

TDA/502/3764763.

TDA/503/178493.

TDA/525/5843888.

TDA/525/5845640.

TDA/525/5844542.

TDA/525/5844609.

TDA/534/5406265.

TDA/534/6025864.

TDA/535/8729404.

TDA/540/12698632.

TDA/540/12698651.

TDA/540/12698737.

TDA/540/12698692.

TDA/540/12698604.

TDA/571/9336605.

TDA/964/18857.

TDA/964/18864.

TDA/964/18849.

TDA/964/18874.

TDA/964/18843.

TDA/964/18845.

TDA/2303/4862684.

TDA/4023/17728641.

TDA/2752/13866667. 


\section{Başbakanlık Cumhuriyet Arşivi (BCA)}

B.C.A, CHP Olağanüstü Büyük Kurultayı Toplantı Zabıtları), Kutu: 218, Gömlek: 860, Sıra: 1, 10 Mayıs 1946.

BCA, (Başbakanlık Özel Kalem Müdürlüğü), 30-1-0-0, Yer: 44-257-1.

\section{Yayınlanmış Arşiv Belgeleri}

British Documents on Foreign Affairs: Reports and Papers From The Foreign Office Confidential PriNT, Part IV, Series B, Vol, 1. (1999). (ed. MalcolmYapp), University Publications of America. (BDOFA-IV-B-1)

British Documents on Foreign Affairs: Reports and Papers from The Foreign Office Confidential Print, Part IV, Series B, Vol 3. (2001). (ed. Malcolm Yapp), University Publications of America. (BDOFA-IV-B-3)

\section{TBMM Zabıt Cerideleri (TBMM-ZC)}

TBMM Zabıt Ceridesi, Dönem: 7, Olağanüstü İnikad, Cilt: 15, 23 Şubat 1945. TBMM Zabıt Ceridesi, Devre VII, İctima 2, Cilt:14, Birinci İnikat, 1 Kasım 1944. TBMM Zabıt Ceridesi, Devre: VII, Toplantı: 3, Cilt:20, Birinci Birleşim, 1 Kasım 1945.

TBMM, Tutanak Dergisi (TBMM-TD), Dönem VII, Toplant1: 8, Cilt: 24, 10 Haziran 1946.

\section{Gazeteler}

Cumburiyet, 12 Temmuz 1946.

Tanin, 13 Temmuz 1946.

Tanin, 18 Temmuz 1946.

Ayın Tarihi, Sayı: 138, 1-31 Mayıs 1945.

\section{Kitap ve Makaleler}

Ahmad, Feroz (2010). Bir Kimlik Peşinde Türkiye. Çev. Sedat Cem Karadeli. İstanbul: İstanbul Bilgi Üniversitesi Yay.

Albayrak, Mustafa (2004). Türk Siyasi Tarihinde Demokrat Parti (1946-1960). Ankara: Phoenix.

Aydın, Mustafa (2002). “İkinci Dünya Savaşı ve Türkiye 1939-1945”. Türk Dış Politikası: Kurtuluş Savaşından Bugüne Olgular, Belgeler, Yorumlar. Ed. Baskın Oran. İstanbul: İletişim Yay. 399-475.

Babaoğlu, Resul (2017). “İngiliz Belgelerinde Türkiye'nin Demokrasiye Geçiş Yılları: Demokrat Parti'nin Kuruluşu ve 1946 Seçimleri”. Sosyal Bilimler Enstitüsü Dergisi 10: 371-402.

Barutçu, Faik Ahmet (1977). Siyasi Anılar. İstanbul: Milliyet Yay.

Bilge, Suat (1992). Güç Komşuluk: Türkiye-Sovyetler Birliğgi İlişkileri 1920-1964. Ankara: İş Bankası Yay. 
Burçak, Rıfkı Salim (1977). Türkiye’de Demokrasiye Geçiş 1945-1950. Ankara: Olgaç Yay.

Demirel, Ahmet (2014). Tek Partinin İktidarı: Türkiye'de Seçimler ve Siyaset. İstanbul: İletişim Yay.

Ekinci, Necdet (1997). II. Dünya Savaşı'ndan Sonra Türkiye’de Çok Partili Düzene Geçişte Dış Etkenler. İstanbul: Toplumsal Dönüşüm Yay.

Erkin, Feridun Cemal (1987). Dışişlerinde 34 Yıl. Ankara: TTK Yay.

Eroğul, Cem (1990). Demokrat Parti Tarihi ve Ídeolojisi. Ankara: İmge Yay.

Hassanli, Jamil (2011). Stalin and Turkish Crises of Cold War. Lanham: Lexington Books.

İnan, Süleyman (2006). Muhalefet Yillarında Adnan Menderes. Ankara: Liberte Yay.

Karpat, Kemal (2015). Türk Demokrasi Tarihi. İstanbul: Timaş Yay.

Koçak, Cemil (2012). Türkiye'de İki Partili Siyasi Sistemin Kuruluş Yilları (19451950): İktidar ve Demokratlar. İstanbul: İletişim Yay.

Koçak, Cemil (2017). Türkiyéde Milli Şef Dönemi. İstanbul: İletişim Yay.

Sever, Ayşegül (1997). Soğuk Savaş Kuşatmasında Türkiye. İstanbul: Boyut Yay.

Tekin, Yusuf ve Çağatay Okutan (2019). Türk Siyasal Hayatı. Ankara: Orion Yay. Timur, Taner (1994). Türkiye'de Çok Partili Hayata Geçiş. İstanbul: İletişim Yay.

Tuncer, Erol (2003). Osmanlidan Günümüze Seçimler (1877-2002). Ankara: TESAV.

Ülman, Halık (1961). Türk-Amerikan Diplomatik Münasebetleri 1939-1947. Ankara: SBF Yay.

Yetkin, Çetin (1983). Türkiye’de Tek Parti Yönetimi 1930-1945. Altın Kitaplar Yay. 


\title{
The 1946 Elections and Its Reflections on International Politics: Transition to Multi- Party Political Life on the Verge of the Cold War ${ }^{*}$
}

\author{
Yusuf Tekin ** \\ İrşat Sanalioğlu**
}

\begin{abstract}
The general elections of 1946, which is considered as the beginning of multi-party system in Turkey is one of the most important elections in the history of Turkish democracy. The elections of 1946, which was attended by more than one political party for the first time, attracted great interest in the academic community in terms of the innovation it brought to Turkish Political life, the discussions on the election process and the relation of the process with foreign policy. There are many studies in the literature regarding the discussions in the domestic politics on the 1946 elections. However, it is not possible to mention enough studies on the reflections of elections in the outside world. In this study, the outlook on Turkey's elections in Western democracies, especially in the England and the USA, and Soviet Russia will be analysed. In this context, after mentioning the domestic and foreign policy conditions in the elections and discussions about the process, the meaning of the elections within the international policy and the interpretation of the elections of the mentioned countries will be examined.
\end{abstract}

\section{Keywords}

Multiparty System, the Elections of 1946, Democratization, Turkish Foreign Policy, Cold War.

\footnotetext{
"Date of Arrival: 17 June 2020 - Date of Acceptance: 17 November 2020

You can refer to this article as follows :

Tekin, Yusuf and İrşat Sarıalioğlu (2021). "1946 Seçimleri ve Uluslararası Politikadaki Yansımaları: Soğuk Savaşın Eşiğinde Çok Partili Siyasal Hayata Geçiş”. bilig - Journal of Social Sciences of the Turkic World 96: 1-32.

" Prof. Dr., Ankara Hacı Bayram Veli University - Ankara/Turkey

ORCID ID: 0000-0002-1385-2945

yusuf.tekin@hbv.edu.tr

"*D. Lecturer, Ankara Hacı Bayram Veli University, Faculty of Economics and Administrative Sciences,

Department of International Relations - Ankara/Turkey

ORCID ID: 0000-0001-7835-0746

irsat.sarialioglu@hbv.edu.tr
} 


\section{Выборы 1946 года и их последствия в международной политике: переход к многопартийной политической жизни на пороге холодной войны}

\section{Юсуф Текин}

\section{Иршат Сарыалиоглу ${ }^{* * *}$}

\section{Аннотация}

Всеобщие выборы 1946 года, которые считаются началом многопартийной системы в Турции, являются одними из самых важных выборов в истории турецкой демократии. Выборы 1946 года, в которых впервые приняли участие более одной политической партии, вызвали большой интерес в академическом сообществе с точки зрения нововведений, которые они внесли в политическую жизнь Турции, дискуссий о процессе выборов и взаимосвязи этого процесса с внешней политикой. В литературе существует много исследований, посвященных дискуссиям во внутренней политике о выборах 1946 года. Однако этого нельзя сказать об исследованиях, посвященных отражению выборов во внешнем мире. В данном исследовании будет проанализировано мнение о выборах в Турции, сложившееся в западных демократиях, особенно в Англии и США, а также в Советской России. В этом контексте, вслед за анализом условий внутренней и внешней политики во время выборов и обсуждением процесса, будет исследовано значение выборов в международной политике и интерпретация выборов в упомянутых странах.

\section{Ключевые слова}

Многопартийность, выборы 1946 года, демократизация, турецкая внешняя политика, холодная война.

\footnotetext{
* Поступило в редакцию: 17 июня 2020 г. - Принято в номер: 17 ноября 2020 г.

Ссылка на статью:

Tekin, Yusuf ve İrşat Sarıalioğlu (2021). "1946 Seçimleri ve Uluslararası Politikadaki Yansımaları: Soğuk Savaşın Eşiğinde Çok Partili Siyasal Hayata Geçiş”. bilig - Журнал Гуманитарныхх Наук Тюркского Мира 96: 1-32.

** Проф., д-р, Университет Хаджи Байрам Вели - Анкара / Турция ORCID ID: 0000-0002-1385-2945

yusuf.tekin@hbv.edu.tr

*** Д-р, преподаватель, Университет Хаджи Байрам Вели, İ.І̇.В.F., кафедра международных отношений - Анкара / Турция ORCID ID: 0000-0001-7835-0746

irsat.sarialioglu@hbv.edu.tr
} 